Resume : Public healt on culture and food on nutrition

Date : 8 Desember 2021

\title{
PENGARUH BUDAYA TERHADAP PANGAN, SISTEM BUDAYA TERHADAP MAKANAN, MASALAH BUDAYA DAN MAKANAN TERHADAP GIZI, SERTA SOLUSI MENGATASI MASALAH BUDAYA DAN MAKANAN TERHADAP GIZI DAN KESEHATAN
}

Irma Anggriani (70200121014)

Kesehatan Masyarakat (A)

Universitas Islam Negeri Alauddin Makassar

Email : irmaanggriani017@gmail.com

\section{PENGARUH BUDAYA TERHADAP PANGAN}

Budaya memiliki pengaruh yang besar dalam menentukan pola makan masyarakat tertentu. Masih banyak pantangan serta mitos yang masih dipercayai masyarakat mengenai pola makan. Makanan adalah suatu unsur budaya yang mencirikan budaya komunitas tertentu. Di Indonesia, keberagaman suku yang dimiliki menyebabkan adanya perbedaan dalam pemilihan makanan pokok. Bagi masyarakat Papua, Sulawesi Tenggara dan NTT, makanan pokok yang dikonsumsi adalah sagu. Olahan makanan yang terbuat dari sagu antara lain , Papeda, kue, es cendol sagu dan lain sebagainya. Sementara itu, masyarakat Bugis mayoritas mengkonsumsi Beras sebagai makanan pokoknya. Olahan makanan yang terbuat dari Beras adalah nasi kuning, nasi goreng, burasa, ketupat dan lain sebagainya. Masyarakat Madura mayoritas mengkonsumsi Jagung sebagai makanan pokoknya. Adanya perbedaan pemilihan makanan pokok ini menunjukkan adanya persepsi dan penilaian terhadap makanan sebagai sebuah budaya pokok di dalam suatu masyarakat. Hal ini dapat menjadi dasar mengapa bagi masyarakat Bugis, jika belum memakan nasi dianggap mereka belum makan meskipun mereka telah jenis makanan berat selain nasi. Pola makan masyarakat 
memiliki perbedaan di setiap daerah. Kepercayaan masyarakat terhadap suatu makanan tertentu dapat menjadi faktor dalam memilih pola konsumsi kalangan tertentu. Pada golongan anak-anak dan remaja, pola makan dipengaruhi oleh budaya masyarakat di tempat mereka tinggal.

\section{SISTEM BUDAYA TERHADAP MAKANAN}

Berbagai sistim budaya memberikan peranan dan nilai yang berbeda-beda terhadap makanan, misalnya bahan-bahan makanan tertentu oleh suatu budaya masyarakat dapat dianggap tabu atau bersifat pantangan untuk dikonsumsi karena alasan sakral tertentu atau sistim budaya yang terkait didalamnya. Disamping itu ada jenis makanan tertentu yang di nilai dari segi ekonomi maupun sosial sangat tinggi eksistensinya tetapi karena mempunyai peranan yang penting dalam hidangan makanan pada sesuatu perayaan yang berkaitan dengan kepercayaan masyarakat tertentu maka hidangan makanan itu tidak diperbolehkan untuk dikonsumsinya bagi golongan masyarakat tersebut.

Sebagai contoh yang berhubungan dengan sistim budaya adalah sering terjadi pada masyarakat di perkotaan yang mempunyai gaya hidup budaya dengan tingkat kesibukan yang tinggi karena alasan pekerjaan. Contohnya; pada ibu-ibu di daerah perkotaan yang kurang dan tidak sering menyusui bayinya dengan Air Susu Ibu (ASI) setelah melahirkan tetapi hanya diberikan formula susu bayi. Padahal kita tahu bahwa ASI sangat penting untuk pertumbuhan dan perkembangan fisik bayi. Selain itu gaya hidup di perkotaan cenderung kurang sehat karena lebih banyak mengkonsmsi makanan cepat saji (junk food), sementara di Pedesaan makanan yang di konsumsi lebih sehat karena dipanen dan di olah sendiri sehingga di ketahui kebersihan dan kualitas makanan tersebut.

Semua aktifitas manusia yang berkaitan dengan religi didasari oleh getaran jiwa yang disebut dengan emosi keagamaan atau religious emotion. Masyarakat dalam kebudayaan tertentu selalu berusaha memelihara emosi keagamaannya diantara pengikut-pengikutnya. Mereka membuat, melaksanakan, dan melindungi sistem keyakinannya, termasuk didalamnya membuat ketentuan tentang upacara keagamaan. Unsur-unsur yang terkait dengan upacara keagamaan biasanya meliputi: bersaji, berkorban, berdoa, makan bersama makanan yang telah disucikan dengan doa, menari tarian suci, berpawai, memainkan seni drama suci, berpuasa, bertapa, bersemedi, dan lain-lain. Unsur-unsur upacara keagamaan ini ada yang dianggap penting sekali dalam suatu agama, tetapi tidak dikenal dalam agama lain, demikian juga sebaliknya. 


\section{MASALAH BUDAYA DAN MAKANAN TERHADAP GIZI}

Mencermati akan adanya budaya, kebiasaan dan sistim sosial masyarakat terhadap makanan seperti pola makan, tabu atau pantangan, gaya hidup, gengsi dalam mengkonsumsi jenis bahan makanan tertentu dari bahan makanan tersebut. Apabila keadaan tersebut berlangsung lama dan mereka juga belum memahami secara baik tentang pentingnya faktor gizi dalam mengkonsumsi makanan maka tidak mungkin dapat berakibat timbulnya masalah gizi atau gizi salah (Malnutrition). Lebih lanjut dijelaskan oleh Suhardjo, 1996 bahwa jika kalangan masyarakat yang terkena dampak dari sistim sosial atau budaya makan itu berasal dari golongan individu-individu yang termasuk rawan gizi seperti ibu hamil, ibu menyusui, bayi dan anak-anak balita serta orang lanjut usia maka kondisi ini akan lebih rentan terhadap timbulnya masalah gizi kurang.

Contoh malnutrition yang terjadi pada balita adalah stunting. Berdasarkan hasil Pemantauan Status Gizi (PSG) 2018, Kabupaten Enrekang, prevalensi stunting pada tahun 2016 sebesar 29,38\% (12,15\% sangat pendek dan 17,23\% pendek) kemudian turun pada tahun 2018 menjadi 24,7\% (7,4\% sangat pendek dan $17,3 \%$ pendek). Hasil data PSG menunjukkan bahwa dari 13 kecamatan di Kabupaten Enrekang diketahui bahwa kecamatan yang memiliki prevalensi stunting tertinggi pada tahun 2018 yaitu Kecamatan Baraka sebesar 45,1\% (27,3\% pendek dan 17,8\% sangat pendek) dari 1.359 balita. Bulan februari tahun 2017, menunjukkan prevalensi stunting sebesar 39,1\% (10,9\% sangat pendek dan 28,2\% pendek) dari 1.537 balita. Hal ini menunjukkan prevalensi stunting di Kecamatan Baraka mengalami kenaikan dari 39,1\% menjadi 45,1\%. Sementara Desa BoneBone yang terletak di Kecamatan Baraka merupakan daerah paling banyak balita penderita stunting yang mencapai 61,29 persen (Dinkes Kabupaten Enrekang, 2018).

Balita usia 24-59 bulan termasuk dalam golongan masyarakat kelompok rentan gizi (kelompok masyarakat yang paling mudah menderita kelainan gizi), sedangkan pada saat itu mereka sedang mengalami proses pertumbuhan yang relatif pesat (Ratih, 2014). Gangguan pertumbuhan linear atau stunting, terjadi terutama dalam 2 sampai 3 tahun pertama kehidupan dan merupakan cerminan dari efek interaksi antara kurangnya asupan energi dan asupan gizi, serta infeksi.

Hasil penelitian ini tidak sejalan dengan penelitian yang dilakukan oleh Rizki dan Lailatul (2016) yang dilakukan di Madura yang menunjukkan bahwa sosial budaya Etnik Mandura mengakibatkan balita mengalami stunting. Hasil penelitian ini menunjukkan bahwa saya sosial budaya bukan hanya faktor yang dapat mengakibatkan terjadinya stunting, namun ada faktor lain seperti yang 
diktakan oleh kepala puskesdes bahwa faktor utama yang mengakibatkan tingginya angka kejadian stunting adalah jarak kehamilan yang terlalu dekat.

Walaupun hasil penelitian ini menunjukkan tidak ada hubungan, ternyata setelah diliat dari pola asuh khususnya praktik pemberian makan pada balita masih ada ibu yang memberikan makanan pendamping ASI (MP-ASI) sebelum umur 6 bulan.Ini menggambarkan bahwa ibu sudah mengetahui pemberian MP ASI sebelum 6 bulan itu tidak benar, namun secara praktik itu tidak dilakukan. Berdasarkan hasil wawancara diketahui bawa ibu yang memberikan MP ASI sebelum 6 bulan diakibatkan karena ibu yang juga merupakan seorang petani sehinnga waktu untuk menyusui kurang dan solusinya adalah pemberian susu formula. ASI eksklusif dapat mempengaruhi kejadian stunting karena jika bayi yang belum cukup umur 6 bulan sudah diberi makanan selain ASI akan menyebabkan usus bayi tidak mampu mencerna makanan dan bayi akan mudah terkena penyakit karena kurangya asupan. Sehingga balita yang sering menderita penyakit infeksi akan menyebabkan pertumubuhannya terhambat dan tidak dapat mencapai pertumbuhan yang optimal (Nurjannah, 2019).

\section{SOLUSI MENGATASI MASALAH BUDAYA DAN MAKANAN TERHADAP GIZI DAN KESEHATAN}

Masalah budaya dan makanan kita ketahui dapat menyebabkan masalah gizi yang berdampak pada kesehatan tubuh manusia, sehingga perlu secara cermat untuk memberdayakan masyarakat lokal dengan kearifan dan kecerdasan lokal (local wisdom and local genius) disamping terus melaksanakan penyuluhan gizi sebagai alternative mengatasi masalah budaya dan makanan.

Menurut Azwar (2004). Solusi yang bisa dilakukan adalah :

1. Dibutuhkan adanya kebijakan khusus untuk mempercepat laju percepatan peningkatan status gizi. Dengan peningkatan status gizi masyarakat diharapkan kecerdasan, ketahanan fisik dan produktivitas kerja meningkat, sehingga hambatan peningkatan ekonomi dapat diminimalkan.

2. Pelaksanaan program gizi hendaknya berdasarkan kajian 'best practice' (efektif dan efisien) dan lokal spesifik. Intervensi yang dipilih dengan mempertimbangkan beberapa aspek penting seperti: target yang spesifik tetapi membawa manfaat yang besar.

3. Melakukan penelitian/pengkajian untuk melihat pengaruh budaya terhadap makanan itu sendiri terhadap implikasi didalamya. 


\section{DAFTAR PUSTAKA}

Dr. Labanudi, SST, M.Kes, 2017, Sosiologi dan Antropologi gizi, Kendari, Forum Ilmiah Kesehatan (FORIKES)

Irviani Ibrahim, Syamsul Alam, dkk. 2021. "Hubungan Sosial Budaya Dengan Kejadian Stunting Pada Balita Usia 24-59 Bulan Di Desa Bone-Bone Kecamatan Baraka Kabupaten Enrekang Tahun 2020” http://journal.uinalauddin.ac.id/index.php/alghidza/article/viewFile/19079/10552, diakses pada tanggal 8 Desember 2021 pukul 22.25 WITA.

Muhammad Dicky Syaifudin, 2020, "Pengaruh Budaya Terhadap Pola Makan Masyarakat". https://www.rancah.com/kuliner/91112/pengaruh-budaya-terhadap-polamakan-masyarakat-indonesia/, diakses pada tanggal 8 Desember 2021 pukul 22.50 WITA. 